\title{
A STRUCTURAL APPROACH TO INTEGRATING TOTAL QUALITY MANAGEMENT AND KNOWLEDGE MANAGEMENT WITH SUPPLY CHAIN LEARNING
}

\author{
Siew-Phaik Loke ${ }^{1}$, Alan G. Downe ${ }^{2}$, Murali Sambasivan ${ }^{3}$, Khalizani Khalid ${ }^{4}$ \\ 1,4 Faculty of Business Management, Universiti Teknologi MARA (UiTM), Bota, Malaysia \\ ${ }^{2}$ School of Business, Curtin University Sarawak, Miri, Malaysia \\ ${ }^{3}$ Graduate School of Management, Universiti Putra Malaysia, Serdang, Malaysia \\ E-mails: ${ }^{1}$ lokesp@gmail.com (correspondingauthor); ${ }^{2}$ adowne@pd.jaring.my; \\ 37murali@econ.upm.edu.my; ${ }^{4}$ lyzakhalid76@gmail.com
}

Received 07 June 2011; accepted 31 August 2011

\begin{abstract}
The aim of this study is to integrate total quality management (TQM) and knowledge management (KM) into a unified framework to study supply chain learning among partnering firms. The impacts of TQM practices (e.g. leadership, strategic planning, customer focus, information analysis, people management and process management) and $\mathrm{KM}$ practices including $\mathrm{KM}$ process, leadership in KM, KM culture, KM technology and KM measurement on supply chain learning were examined. In this study, mail questionnaire have been sent to the managers consists of the Malaysian manufacturing and service firms. A total of 202 firms participated in this study. While greater level of TQM practices tends to enhance KM practices, we found that both TQM and KM are significantly positively related to supply chain learning. The findings of this study empirically tested and confirmed the proposed integrated model. It is hoped that findings from this paper can provide greater understanding in the areas of quality and knowledge management, and illustrate how these practices can enrich the supply chain learning among partnering firms.
\end{abstract}

Keywords: TQM, quality management, knowledge management, supply chain, Malaysia, structural equation modelling.

Reference to this paper should be made as follows: Loke, S.-P.; Downe, A. G.; Sambasivan, M.; Khalid, K. 2012. A structural approach to integrating total quality management and knowledge management with supply chain learning, Journal of Business Economics and Management 13(4): 776-800.

JEL Classification: M11.

\section{Introduction}

The success of supply chain management (SCM) depends largely on the firm's efficiency in managing its processes. SCM is regarded as a powerful vehicle in cost reduction overall and performance improvement. It can also increase a firm's competitiveness if it is well-managed. The origin of SCM is perceived to derive from logistics management (Lee, Kincade 2003; Cox 1999; Tan et al. 2002) and Romano and Vinelli (2001) 
referred it as integrated logistics management. SCM has evolved from a functional focus to cross-functional collaborations. This collaborative strategy has gained popularity among supply chain firms particularly due to the need for global market presence and increased customer demands. Effective collaboration are useful for capturing cost savings, enhancing customer satisfaction, facilitating synergies, adding value to all supply chain partners and ultimately remaining competitive in the industry. Slack, Chambers and Johnston (2004) argued that supply chain activities consist of purchase and supply management, physical distribution management, logistics and material management. Overall, SCM includes the sourcing of raw materials, productions, new product development and commercialization, sales and marketing, product returns and recycling, and managing supplier and customer relations (Lockamy, McCormack 2004; Mills et al. 2004; Talib et al. 2011).

Networking and collaboration enhance firm's performance. Literature within SCM documented the need for cooperation due to the emergence of quality management philosophies. Therefore, this has resulted the study on the linkages between adoption of total quality management (TQM) practices and organizational outcomes such as learning and knowledge transfer. Interestingly, Sohal and Morrison (1995) highlighted that TQM initiatives can only lead to organizational learning if such quality efforts are supported with a conducive environment that can help firms to emerge as learning organizations and continuously to acquire new knowledge about customers, suppliers, processes and employees. A recent study by Vanichchinchai and Igel (2009) suggested that TQM and SCM share similar characteristics which both involve internal function participations and external partnerships. They added that while the main focus of TQM is on participation from all internal function, the SCM put emphasis on continuous collaboration with external partners.

TQM and SCM are said to be the most important strategies for many different companies: from small-to-medium sized enterprises (SMEs) to giant manufacturers and servicing companies. TQM are often applied for process variance reduction which is directly linked to supply chain performance measures such as cycle time, order fulfillment and delivery dependability. Embracement of quality initiatives within SCM practices aims to achieve better product quality and development (Carmignani 2009). According to Dick (2000), firms with a strong commitment to TQM have better business performance improvement than firms who only possessed QCert (e.g. ISO 9000 certification). Kuei, Madu and Lin (2001) found that supply chain quality factors have positive impact on organizational performance. To a certain extent, SCM relies on TQM to effectively integrate suppliers, manufacturers, distributors and customers. Improvements in supplier quality management, customers' relations and supplier selection contribute to increased organizational performance (Kuei et al. 2001).

The quality perspective of supply chain management claims that focuses on quality management practices is a critical success factor to the firm because better product would lead to new customer attraction and retention of existing customers (Kordupleski et al. 1993; Kuei et al. 2001). Since TQM, learning and knowledge management (KM) drawing from a common notion - organizational development (Zetie 2002), it is logical 
to examine if there is a linkage exists between these concepts, and if so, what would be the direction of the relationships. Learning involves the accumulation of knowledge and it helps firms to create new knowledge-related capabilities. Nielsen (2005) added that these capabilities can be in the form of tacit and fairly dynamic in nature. Efficient $\mathrm{KM}$ in supply chains enhance firm innovation and creativity to survive in today's rapidly changing business world (Maqsood et al. 2007; Sambasivan et al. 2009). Schein (2002) noted the difficulty in establishing a learning organization although knowledge is known to be a powerful source of firms' competitiveness. It is even more challenging to expand the learning behavior across different organizational boundaries. This is because firms are encouraged to learn and acquire skills, products, technology and knowledge through value creating activities (Spekman et al. 2002) meanwhile striving to keep their own proprietary information and core competencies. Jabar, Soosay and Santa (2011) argued that firms are more protective of their knowledge when their partners have high learning intent. However, high levels of trust between these partners foster continuous information sharing and exchange.

While supply chains provide an environment where the partnering members can benefit from learning processes based on the transfer of skills and knowledge (Sambasivan et al. 2009), different levels of absorptive capacity among these members can complicate the knowledge acquisition process. Simply, some firms learn better and faster than others. Prior researchers, such as Cohen and Levinthal (1990) and Lane, Salk and Lyles (2001) have described it as a firm's absorptive capacity. Cohen and Levinthal (1990) defined absorptive capacity as the level of knowledge overlap between partners, including the ability of a firm to value, assimilate and commercially utilize new, external knowledge. In the present study, we included the concept of absorptive capacity as a component of learning within the supply chain.

The aims of this study are twofold: first, we sought to develop an integrated TQM and KM model of supply chain learning (SCL). Second, we empirically tested the integrated model using data drawn from both manufacturing and services firms through structural model. The following section describes the literature review of the studied variables and details the construction of the model and formulation of hypotheses. Finally, we present the data analysis, research findings and discussion, including directions for future research.

\section{Literature review}

\subsection{Total quality management}

Firms today are facing on-going challenges from global competition and more sophisticated customers in terms of what they want and need (McAdam, Henderson 2004; Tan et al. 2002). Many firms adopt quality management programs in order to achieve high degree of differentiation and to reduce costs (Tarí 2005). TQM refers to a management approach to planning and implementing continuous improvement throughout the entire firm for performance improvement (Claver-Cortes et al. 2008; Teh et al. 2008). According to Tarí (2005), there are standardized models to guide firms in implementing and 
self-assess their quality practices, including those associated to the Malcolm Baldrige National Quality Award (MBNQA) in the USA, the European Foundation for Quality Management (EFQM) in Europe and the Deming Application Prize in Japan.

Numerous studies have been carried out to examine critical success factors for TQM implementation, tools and techniques for quality improvement, different categories of TQM practices and the evaluation of TQM implementation in various industry settings, including services sectors. A recent study by Talib et al. (2011) reported an intensive review of TQM, finding that top management commitment, customer focus, training and education, continuous improvement and innovation, supplier management, and employee involvement are major practices for TQM.

In this study, we adopt an approach similar to those used in previous research (e.g. Choi, Eboch 1998; Samson, Terziovski 1999; Prajogo, Sohal 2003; Lee et al. 2003; Hsieh et al. 2007; Prajogo, Hong 2008; Teh et al. 2008) in describing TQM practices. The six constructs are leadership, strategic planning, customer focus, process management, information analysis and human resource focus.

\subsection{Knowledge management}

KM emerged as a distinct management discipline when firms began shifting their focus from traditional factors of production to intangible assets such knowledge and goals focused on continuously meeting and exceeding customer's needs (Nielsen 2005; Jasimuddin 2008; Loke et al. 2010). Research in the areas of organizational learning and knowledge management are said to have developed in the 1960s (Cyert, March 1963). Zack, Mckeen and Singh (2009) noted that published work in the KM area consists conceptual frameworks, theoretical models and empirical research that relies largely on qualititative case studies.

$\mathrm{KM}$ is a core competency for firms in the era of knowledge-based economies (Chong, C. W.; Chong, S. C. 2009; Grant, Baden-Fuller 2004; Johannessen, Olsen 2003). Knowledge workers are frequently to be key assets in a knowledge-based society (Drucker 1993). Although there the direct relationship between KM practices and financial performance has been elusive, Zack et al. (2009) established a positive direct relationship between KM practices and organizational performance which, in turn, directly influences financial performance. Ho (2008) reported that firms can create syneristic effects on performance through implementation of external tacit-internal-oriented and explicit-external-oriented KM strategies.

$\mathrm{KM}$ is important for firms wishing to operate in a rapidly changing business environment as it enchances firms' abilities to strategically leverage knowledge to be their main source of competitive advantages. According to Lin (2011), "KM practices aim to see individual knowledge become group and organizational knowledge over time, which in turn improves the stock of knowledge available to the firm" (p. 136). The present study views KM practices in the same way. We hypothesized that the benefits of individual knowledge accumulation within a firm can be extended to improved performance of the supply chain members. 


\subsection{Supply chain learning}

Much of the existing literature on KM has paid little attention to learning specifically dedicated to the supply chain. Yet, it is becoming clear that firms operate within a value stream that involves other firms within a business network (Bessant et al. 2003). Bessant et al. (2003) argued that shared learning between firms offers potential as a mechanism to enhance firm's competitiveness. Learning facilitates international joint venture partners to gain access to others' know-how or resources (Akande et al. 2010).

Work by Claycomb, Dröge, and Germain (2001) and Spekman et al. (2002) pioneered the conceptual development of supply chain learning (SCL). Claycomb et al. (2001) classified knowledge applied to facilitated exchange within supply chains to: (1) upstream, where exchange happens between the firm and its suppliers; (2) within the firm itself where exchange happens to enhance its operation; and (3) downstream, where exchange happens between firms and its customers or distributors. According to Spekman et al. (2002), process efficiency and improved performance requires a learning environment among supply chain members. Specifically, pre-conditions for learning such as integrative mechanisms and shared culture, learning enablers and learning structure and support must be present so that positive impact on performance can be derived.

Fahey et al. (2001) identified key knowledge issues of know-what, know-how and know-why related to SCM. For example: what changes are needed within the supply chain to lower costs and increase responsiveness? (know-what); how can one use supply chain transparency to make informed operational decisions? (know-how); why is it necessary to regularly re-evaluate SCM processes? (know-why). Bessant et al. (2003) acknowledged the different components of SCL and explained that the potential for such learning can range from simple incremental additions (such as new regulations) to a current knowledge set (such as a new and complex approach which involves experiments and adaptation). A recent study by Sambasivan et al. (2009) added the component of environmental knowledge in examining the relationships between SCL, SCM process knowledge and organizational performance. They found that three types of environmental knowledge (demand predictability, product churning and process change) moderated the relationship between applied supply chain process knowledge and organizational performance. Regardless of how researchers define and view KM and learning within a supply chain, this business strategy supports collaboration and decision-making which, in turn, builds firms' competitiveness.

\section{Model development and hypotheses formulation}

An integrated model was used to test the relationships among TQM, KM and SCL (see Fig. 1).

The causal relationships, depicted by arrows, were investigated by LInear Structural RElations software (LISREL) through SEM. The theoretical bases of the relationships among the constructs are discussed hereafter. 


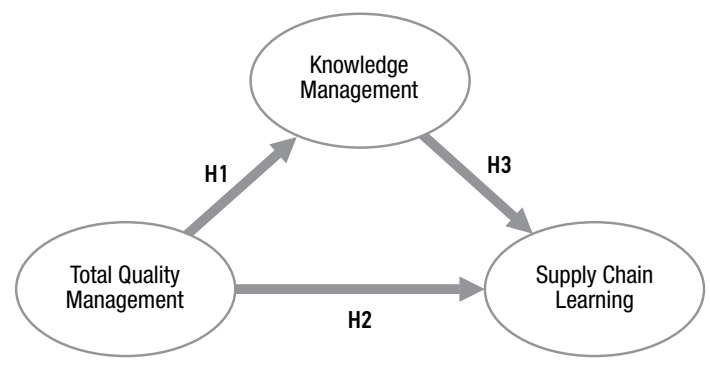

Fig. 1. Research model

\subsection{Relationships between total quality management, knowledge management and supply chain learning}

TQM embodies the basic principles of quality assurance, total quality control and firmwide quality control. It is a set of management practices that is applied throughout organizations aiming to ensure customer satisfaction are met (Talib et al. 2011). Introducing and implementing TQM practices requires a long term commitment and through continuous improvement, it enables firms to achieve conformance to product specification and reduction of variances. TQM is found to be positively associated with competitiveness in terms of improved productivity and cost reduction (Sohal, Morrison 1995). Many researchers have also noted the importance of quality in long-term sustainability and future competitiveness (Talib et al. 2011; Phusavat, Kanchan 2008).

The purpose of TQM and KM practices focuses on work-processes improvement on a firm so that high customer satisfaction can be derived. TQM emphasizes on quality improvement in all functional areas and at all levels in a firm. Whereas KM practices play an important role to enable embed learning processes (before, during and after execution of plans) into the way management plan, execute and evaluate performance for continuous improvement (Lyons et al. 2008). Zetie (2002) identified the close relationship between TQM and KM through the following:

(a) Deming's emphasis throughout many of his later writings on the concept of "profound knowledge" as a cornerstone of quality; and,

(b) the realization that an organization's quality manual is the depository of its process knowledge (p. 318).

The Deming Wheel, or Plan-Do-Check-Act (PDCA) cycle is a four-stage process for continuous quality improvement that complements Deming's overall philosophy for achieving improvement. Each stage of the PDCA cycle relies heavily on documentation to reduce process variation. Decreasing error rates (control) is found to be less important as compared to experimentation (learning) in highly uncertain contexts (Mellat-Parast, Digman 2008). According to Ju et al. (2006), integrating quality management and KM can be valuable to the organizations since it increases implementation options, particularly for those effecting organizational changes. More importantly, TQM focuses on improvement in learning capability under highly uncertain environments (Mellat-Parast, Digman 2008; Sitkin et al. 1994). Sitkin et al. (1994) introduced the concept of total 
quality learning (TQL) which stresses improvement in learning capability. Such learning capability "includes effectively identifying new skills and resources to pursue, the ability to explore these new arenas, the capacity to learn from that exploration, and the resilience to withstand the inevitable failures associated with such exploration" (p. 546). Recognizing the relationship between TQM and KM is crucial as it helps to expand a broader use of explanatory models developed in a specific context by Zetie (2002) and to confirm arguments by Sitkin et al. (1994). Therefore, we posit the following hypothesis:

H1: TQM practices will have a significant positive impact on KM practices.

Vanichchinchai and Igel (2009) noted that today's customers demand better product quality, faster delivery and cheaper costs. By maintaining and sustaining customerdriven culture, that is to offer the right product in the right place at the right time and at the right prices enable firms to achieve customer satisfaction and retention (Fisher et al. 2000). Spekman et al. (2002) argued that with an effective integrated supply chain, partnering firms are able to enjoy reduction of cost, process improvement and new product development through enhanced innovation capabilities. Development of capabilities and skills are thus required to compete in the fast changing business world (Chawla, Joshi 2010). Quality improvement significant reduces the amount of rework or inefficiency. Lin et al. (2005) added that firm's effective management of technology and quality lead to better market position and increased competitiveness.

Prior studies by Manning, Baines and Chadd (2006) and Schröder and McEachern (2002) acknowledged the potential of quality assurance models in supporting supply chain integration and integrity of product specification. The influence of TQM practices on organizational learning can be taken to a further step by expanding it to the entire supply chain. This is because there is a paradigm shift focuses on managing supply chain networks and joint development of quality products (Levy 1998; Kuei, Madu 2001; Lin et al. 2005).

Using Australian-based firms, Sohal and Morrison (1995) found that TQM is part of becoming a learning organization. They further suggested that firms are required to be well-versed at (1) systematic problem solving; (2) experimentation with new approaches; (3) learning from its own experiences; (4) learning from experiences and best practice of others; and (5) transferring knowledge throughout the organization, in order to become a learning organization. Activities of learning, re-learning and un-learning enable collaborating firms in the supply chain to evaluate and monitor performance so that any improvement plans can be proposed to enhance mutual benefits (Loke et al. 2011). Therefore, we posit the following hypothesis:

H2: TQM practices will have a significant positive impact on supply chain learning.

\subsection{Relationship between knowledge management and supply chain learning}

The proliferation of supply chain partnerships is largely due to its benefits from cost reduction to synergies creation (Loke et al. 2009). While witnessing the increase in numbers of collaborative ventures such as strategic alliances, joint ventures, market- 
ing agreements, outsourcing relationships and research consortia, Nielsen (2005) highlighted that collaboration today focusing on intangible assets such as knowledge rather than mere management of physical goods. Chen et al. (2009) found that collaboration enhances dynamic learning in creating dynamic competitive capabilities. Chen et al. (2009) further argued that these dynamic competitive capabilities can lead to creativity, evolution and recombination of resources. Firms are encouraged to pay close attention on key strategic issue such as how to leverage a partner' capabilities beyond tangible assets and explicit knowledge (Spekman et al. 2002) as some of these skills and assets are tacit and not easily codified but contribute to the firm's competitiveness (Hall 1999). Nielsen (2005) noted that learning and KM application lead to networking and collaboration. His logic is straightforward: tacit knowledge is often hard to codify and transfer which therefore requires working closely in supporting the development of new knowledge-related capabilities.

According to Loke et al. (2010), the learning activities can be directly related to KM since learning serves to be the main building block for knowledge transfer. Such knowledge acquisition or creation is closely associated with the addition of knowledge or correction of existing knowledge (Shin et al. 2001). KM practices are key to partnering firms in the supply chain for coordination of daily operational tasks, joint decisionmaking and problem-solving. These activities cause changes within their knowledge repository. Collectively, these changes would then become a crucial source for partnering firms to adapt in serving their customers.

Sambasivan et al. (2009) reported that the effective application of knowledge play an important role in supply chain learning. They explained that knowledge creation and transfer are useful for supply chain members in developing new products and services, and in improving operational and process efficiency. Spekman et al. (2002) argued that the principle of knowledge as a competitive advantage can be so powerful that these benefits could be extended from an individual partnering firm to an entire supply chain. Therefore, we posit the following hypothesis:

H3: Knowledge management will have a significant positive impact on supply chain learning.

\section{Research methodology}

\subsection{Sampling procedures}

In this study, we targeted managers from both manufacturing and services companies from the Federation of Malaysian Manufacturers (FMM) Directory 2010 regardless whether the firms were certified with the ISO 9000 quality system series. The level of analysis was the managers who had adequate knowledge about their firms' practices related to quality management, learning and knowledge management. Mail surveys were sent to a random sample of 1,200 managers. Based on 1,200 questionnaires originally distributed, a total of 202 were returned with complete answers yielding an overall response rate of $16.83 \%$. 


\subsection{Research instrument}

\subsubsection{Independent variables: TQM practices}

We adopted the six constructs of TQM included in an earlier study by Teh et al. (2008): leadership; strategic planning; customer focus; process management; information analysis; and human resource focus. Using a 5-point Likert scale ranging from $1=$ strongly disagree to $5=$ strongly agree, each construct was measured by a total of 5 statements. Sample statements are: "Top management strongly encourages employee involvement in quality management and improvement activities" (Leadership); "Our company has a comprehensive and structured planning process which regularly sets and reviews shortand long-term goals" (Strategic Planning); "Quality-related customer complaints are treated with top priority" (Customer Focus); "Employees are encouraged to develop new and innovative ways for better performance" (Process Management); "Up-to-date data and information on company is always readily available" (Information Analysis); "Employee satisfaction is formally and regularly measured" (Human Resource Focus).

\subsubsection{Independent variables: KM practices}

Similar to a previous study conducted by Chawla and Joshi (2010), we used the Knowledge Management Assessment Tool (KMAT) to examine KM practices of responding firms. The KMAT was developed by the American Productivity \& Quality Center (APQC) and Arthur Anderson in 1995 to help organizations self-assess where their strengths and opportunities lie in managing knowledge. The KMAT tool measures 5 constructs of KM practices, namely knowledge management process, leadership in knowledge management, knowledge management culture, knowledge management technology and knowledge management measurement. Using a 5-point Likert scale where $1=$ no, $2=$ poor, $3=$ fair, $4=$ good, $5=$ excellent, variables were measured with a total of 24 statements. Sample statements are: "All members of the organization are involved in looking for ideas in traditional and non-traditional places" (Knowledge Management Process); "Managing organizational knowledge is central to the organization's strategy" (Leadership in Knowledge Management); "The organization encourages and facilitates knowledge sharing" (Knowledge Management Culture); "Technology creates an institutional memory that is accessible to the entire enterprise" (Knowledge Management Technology); and, "The organization has invented ways to link knowledge to financial results" (Knowledge Management Measurement).

\subsubsection{Dependent variables: supply chain learning}

SCL was measured with an adaptation of scales used by Spekman et al. (2002) and Jabar et al. (2011). Selection of both scales comprise criteria to measure both absorptive capacity and learning behavior of the responding firms. Five constructs were used to measure supply chain learning, namely absorptive capacity; five aspects of pre-learning conditions; learning enablers; learning support/systems; and two aspects of joint efforts. All constructs were measured using a 5-point Likert scale ranging from $1=$ strongly disagree to $5=$ strongly agree, except for the integrative mechanism variable, which 
was measured using a 5-point Likert scale ranging from $1=$ very low to $5=$ very high. Sample statements are: "Our company will select partners that are willing to transfer their tacit or unwritten knowledge" (Absorptive Capacity); "Our company and the supply chain partner have a shared continuous improvement philosophy" (Pre-Learning Conditions: Shared Culture); "We are willing to devote extra effort to sustaining this relationship" (Pre-Learning Conditions: Commitment); "Our supply chain partner is trustworthy" (Pre-Learning Conditions: Trust); "Frequent communication occurs between our company and the supply chain partner" (Pre-Learning Conditions: Communication); "The extent of use of IT integration with all suppliers/customers" (PreLearning Conditions: Integrative Mechanisms); "Developing new insights is important to this supply chain" (Learning Enablers); "The systems and procedures of this supply chain support innovation transfer between supply chain partners" (Learning Support/ Systems); "We establish a joint team to manage our relationship" (Joint Efforts: Joint Decision-Making); "We sense that our partner has a willingness to help when problems arise" (Joint Efforts: Win-win Approach).

\subsection{Data analysis}

In this study, we analyzed the collected data using the Statistical Package for Social Sciences (SPSS for Windows). To assess the unidimensionality of each factor, a Confirmatory Factor Analysis (CFA) was carried out (Anderson, Gerbing 1988) using LISREL. Goodness-of-fit index (GFI) and root mean square error of approximation (RMSEA) were used to determine the construct validity. While GFI values closer to 1.00 indicate better fit, lower values of RMSEA are required to demonstrate the goodness-of-fit of the measurement model. The results revealed that the Goodness of Fit Indexes (GFI) for all these factors greater than 0.90 according to Bagozzi and Yi (1988), while the values of RMSEA are less than 0.08 as suggested by Browne and Cudek (1993) and therefore, implying that the unidimensionality (Sureshchandar et al. 2002; Al-Hawari, Ward 2006).

The convergent validity was also tested by assessing the appropriate $p$ values and the factor loadings. According to Fornell and Larcker (1981), convergent validity was assessed for the measurement model based on three conditions: (1) The normal rules of all indicator factor loadings $(\lambda)$ should be significant and exceed 0.50 for acceptability; (2) The average variance extracted (AVE) of each factor should be at least 0.5 or higher; and (3) the scale composite reliability should be greater than 0.60 as reported by Bagozzi and Yi (1988). As shown in the results (Table 1), the $\lambda$-values for all items were well above 0.50 (Kline 1998); Composite Reliability (CR) of all latent factors were above the standard value of 0.7 (Molina et al. 2007), whereas the Average Variance Extracted (AVE) of each factor exceeded 0.5 (Molina et al. 2007: 691), representing good convergent validity, entailing that the measurement is acceptable (Gorla et al. 2010). The results of the AVE and Composite reliability for constructs are illustrated in Table 1.

Structural equation models and path analyses were estimated using the same version of LISREL. 
S.-P. Loke et al. A structural approach to integrating total quality management and knowledge management ...

Table 1. Results of reliability and validity Test $(n=202)$

\begin{tabular}{|c|c|c|c|c|c|c|c|}
\hline \multirow[b]{2}{*}{ Variables and Items } & \multirow{2}{*}{ 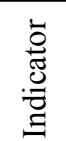 } & \multirow{2}{*}{ 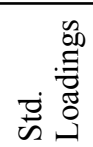 } & \multirow[b]{2}{*}{ 苞苞 } & \multicolumn{2}{|c|}{ Reliability Test } & \multirow[b]{2}{*}{$\mathrm{AVE}^{* *}$} & Validity Test \\
\hline & & & & $\begin{array}{c}\text { Chrobach } \\
\text { Alpha }\end{array}$ & $\begin{array}{l}\text { Composite } \\
\text { Reliability* }\end{array}$ & & GFI RMSEA \\
\hline
\end{tabular}

Total Quality Management

\begin{tabular}{|c|c|c|c|c|c|c|c|c|}
\hline \multirow{5}{*}{$\begin{array}{l}\text { Leadership } \\
\text { (LD) }\end{array}$} & LD1 & 0.82 & 5 & 0.908 & 0.9091 & 0.6964 & 0.98 & 0.078 \\
\hline & LD2 & 0.87 & & & & & & \\
\hline & LD3 & 0.82 & & & & & & \\
\hline & LD4 & 0.77 & & & & & & \\
\hline & LD5 & 0.80 & & & & & & \\
\hline \multirow{5}{*}{$\begin{array}{l}\text { Strategic Planning } \\
\text { (SP) }\end{array}$} & SP1 & 0.73 & 5 & 0.852 & 0.8486 & 0.5422 & 0.99 & 0.041 \\
\hline & SP2 & 0.73 & & & & & & \\
\hline & SP3 & 0.82 & & & & & & \\
\hline & SP4 & 0.75 & & & & & & \\
\hline & SP5 & 0.64 & & & & & & \\
\hline \multirow{5}{*}{$\begin{array}{l}\text { Customer Focus } \\
\text { (CF) }\end{array}$} & CF1 & 0.79 & 5 & 0.892 & 0.8938 & 0.6274 & 0.98 & 0.080 \\
\hline & CF2 & 0.78 & & & & & & \\
\hline & CF3 & 0.81 & & & & & & \\
\hline & CF4 & 0.78 & & & & & & \\
\hline & CF5 & 0.80 & & & & & & \\
\hline \multirow{5}{*}{$\begin{array}{l}\text { Process } \\
\text { Management } \\
(\mathrm{PM})\end{array}$} & PM1 & 0.77 & 5 & 0.881 & 0.8779 & 0.5897 & 0.98 & 0.052 \\
\hline & PM2 & 0.78 & & & & & & \\
\hline & PM3 & 0.78 & & & & & & \\
\hline & PM4 & 0.76 & & & & & & \\
\hline & PM5 & 0.75 & & & & & & \\
\hline \multirow{5}{*}{$\begin{array}{l}\text { Information \& } \\
\text { analysis } \\
\text { (IA) }\end{array}$} & IA1 & 0.88 & 5 & 0.920 & 0.9056 & 0.6582 & 0.99 & 0.045 \\
\hline & IA2 & 0.75 & & & & & & \\
\hline & IA3 & 0.78 & & & & & & \\
\hline & IA4 & 0.80 & & & & & & \\
\hline & IA5 & 0.84 & & & & & & \\
\hline \multirow{5}{*}{$\begin{array}{l}\text { Human Resource } \\
\text { (HR) }\end{array}$} & HR1 & 0.77 & 5 & 0.885 & 0.8945 & 0.6302 & 0.98 & 0.067 \\
\hline & HR2 & 0.76 & & & & & & \\
\hline & HR3 & 0.86 & & & & & & \\
\hline & HR4 & 0.85 & & & & & & \\
\hline & HR5 & 0.72 & & & & & & \\
\hline
\end{tabular}


Continue of Table 1

\begin{tabular}{|c|c|c|c|c|c|c|c|}
\hline \multirow[b]{2}{*}{ Variables and Items } & \multirow{2}{*}{$\begin{array}{l}\dot{0} \\
\stackrel{0}{0} \\
: 0 \\
\Xi\end{array}$} & \multirow{2}{*}{ 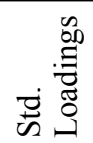 } & \multirow[b]{2}{*}{ 胥 } & \multicolumn{2}{|c|}{ Reliability Test } & \multirow[b]{2}{*}{$\mathrm{AVE}^{* *}$} & Validity Test \\
\hline & & & & $\begin{array}{c}\text { Chrobach } \\
\text { Alpha }\end{array}$ & $\begin{array}{l}\text { Composite } \\
\text { Reliability* }\end{array}$ & & GFI RMSEA \\
\hline
\end{tabular}

Knowledge management

\begin{tabular}{|c|c|c|c|c|c|c|c|c|}
\hline \multirow{5}{*}{$\begin{array}{l}\text { Knowledge } \\
\text { Management } \\
\text { Process (KMP) }\end{array}$} & KMP1 & 0.88 & 5 & 0.890 & 0.9142 & 0.6827 & 0.98 & 0.051 \\
\hline & KMP2 & 0.76 & & & & & & \\
\hline & KMP3 & 0.90 & & & & & & \\
\hline & KMP4 & 0.75 & & & & & & \\
\hline & KMP5 & 0.83 & & & & & & \\
\hline \multirow{4}{*}{$\begin{array}{l}\text { Leadership in KM } \\
\text { (LKM) }\end{array}$} & LKM1 & 0.76 & 4 & 0.904 & 0.8596 & 0.6050 & 1.00 & 0.000 \\
\hline & LKM2 & 0.80 & & & & & & \\
\hline & LKM3 & 0.80 & & & & & & \\
\hline & LKM4 & 0.75 & & & & & & \\
\hline \multirow[t]{5}{*}{ KM culture (KMC) } & $\mathrm{KMC1}$ & 0.78 & 5 & 0.907 & 0.9223 & 0.7041 & 0.98 & 0.043 \\
\hline & KMC2 & 0.90 & & & & & & \\
\hline & KMC3 & 0.87 & & & & & & \\
\hline & KMC4 & 0.83 & & & & & & \\
\hline & KMC5 & 0.81 & & & & & & \\
\hline \multirow{5}{*}{$\begin{array}{l}\text { KM Technology } \\
\text { (KMT) }\end{array}$} & KMT1 & 0.84 & 5 & 0.918 & 0.9139 & 0.6802 & 0.99 & 0.022 \\
\hline & KMT2 & 0.80 & & & & & & \\
\hline & KMT3 & 0.78 & & & & & & \\
\hline & KMT4 & 0.82 & & & & & & \\
\hline & KMT5 & 0.88 & & & & & & \\
\hline \multirow{4}{*}{$\begin{array}{l}\text { KM Measurement } \\
(\mathrm{KMM})\end{array}$} & KMM1 & 0.79 & 4 & 0.901 & 0.8672 & 0.6203 & 0.98 & 0.068 \\
\hline & KMM2 & 0.79 & & & & & & \\
\hline & KMM3 & 0.77 & & & & & & \\
\hline & KMM4 & 0.80 & & & & & & \\
\hline
\end{tabular}

Supply Chain Learning

\begin{tabular}{lllllllll}
\hline Absorptive & AC1 & 0.81 & 4 & 0.889 & 0.8805 & 0.6484 & 0.99 & 0.047 \\
\cline { 2 - 7 } & AC2 & 0.83 & & & & & & \\
\cline { 2 - 7 } & AC3 & 0.78 & & & & & & \\
\cline { 2 - 7 } & AC4 & 0.80 & & & & & & \\
\hline
\end{tabular}


S.-P. Loke et al. A structural approach to integrating total quality management and knowledge management ...

Continue of Table 1

\begin{tabular}{|c|c|c|c|c|c|c|c|c|c|}
\hline \multirow{2}{*}{\multicolumn{2}{|c|}{ Variables and Items }} & \multirow{2}{*}{$\begin{array}{l}\ddot{0} \\
\stackrel{0}{0} \\
: 0 \\
\Xi\end{array}$} & \multirow{2}{*}{ 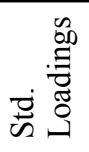 } & \multirow[b]{2}{*}{ 苞 苞 } & \multicolumn{2}{|c|}{ Reliability Test } & \multirow[b]{2}{*}{$\mathrm{AVE}^{* *}$} & \multicolumn{2}{|c|}{ Validity Test } \\
\hline & & & & & $\begin{array}{l}\text { Chrobach } \\
\text { Alpha }\end{array}$ & $\begin{array}{l}\text { Composite } \\
\text { Reliability* }\end{array}$ & & GFI & RMSEA \\
\hline \multirow{18}{*}{ 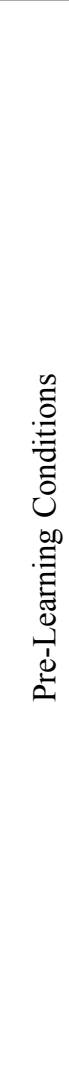 } & \multirow{4}{*}{$\begin{array}{l}\text { Shared } \\
\text { Culture } \\
(\mathrm{SC})\end{array}$} & $\mathrm{SC} 1$ & 0.69 & 4 & 0.913 & 0.8567 & 0.6008 & 0.99 & 0.055 \\
\hline & & $\mathrm{SC} 2$ & 0.77 & & & & & & \\
\hline & & $\mathrm{SC} 3$ & 0.87 & & & & & & \\
\hline & & $\mathrm{SC} 4$ & 0.76 & & & & & & \\
\hline & \multirow{3}{*}{$\begin{array}{l}\text { Commit- } \\
\text { ment } \\
\text { (C) }\end{array}$} & $\mathrm{C} 1$ & 0.89 & 3 & 0.907 & 0.8537 & 0.6142 & 1.00 & 0.000 \\
\hline & & $\mathrm{C} 2$ & 0.84 & & & & & & \\
\hline & & $\mathrm{C} 3$ & 0.70 & & & & & & \\
\hline & \multirow{3}{*}{$\begin{array}{l}\text { Trust } \\
(\mathrm{T})\end{array}$} & $\mathrm{T} 1$ & 0.80 & 3 & 0.844 & 0.8267 & 0.6625 & 1.00 & 0.000 \\
\hline & & $\mathrm{T} 2$ & 0.80 & & & & & & \\
\hline & & $\mathrm{T} 3$ & 0.75 & & & & & & \\
\hline & \multirow{3}{*}{$\begin{array}{l}\text { Communi- } \\
\text { cation } \\
\text { (CO) }\end{array}$} & $\mathrm{CO} 1$ & 0.93 & 4 & 0.910 & 0.9328 & 0.8223 & 0.99 & 0.021 \\
\hline & & $\mathrm{CO} 2$ & 0.89 & & & & & & \\
\hline & & $\mathrm{CO} 3$ & 0.90 & & & & & & \\
\hline & \multirow{5}{*}{$\begin{array}{l}\text { Integrative } \\
\text { Mechanism } \\
\text { (IM) }\end{array}$} & IM1 & 0.78 & 5 & 0.938 & 0.8875 & 0.6019 & 0.99 & 0.006 \\
\hline & & IM2 & 0.88 & & & & & & \\
\hline & & IM3 & 0.83 & & & & & & \\
\hline & & IM4 & 0.76 & & & & & & \\
\hline & & IM5 & 0.65 & & & & & & \\
\hline \multirow{6}{*}{\multicolumn{2}{|c|}{$\begin{array}{l}\text { Learning Enablers } \\
\text { (LE) }\end{array}$}} & LE1 & 0.78 & 6 & 0.933 & 0.9156 & 0.6445 & 0.98 & 0.014 \\
\hline & & LE2 & 0.80 & & & & & & \\
\hline & & LE3 & 0.89 & & & & & & \\
\hline & & LE4 & 0.75 & & & & & & \\
\hline & & LE5 & 0.78 & & & & & & \\
\hline & & LE6 & 0.81 & & & & & & \\
\hline \multirow{5}{*}{\multicolumn{2}{|c|}{$\begin{array}{l}\text { Learning } \\
\text { Structures/ } \\
\text { System/ } \\
\text { Process (LS) }\end{array}$}} & LS1 & 0.88 & 5 & 0.917 & 0.9200 & 0.6685 & 0.99 & 0.034 \\
\hline & & $\mathrm{LS} 2$ & 0.82 & & & & & & \\
\hline & & LS3 & 0.74 & & & & & & \\
\hline & & LS4 & 0.86 & & & & & & \\
\hline & & LS5 & 0.78 & & & & & & \\
\hline
\end{tabular}


End of Table 1

\begin{tabular}{|c|c|c|c|c|c|c|c|c|c|}
\hline \multirow{2}{*}{\multicolumn{2}{|c|}{ Variables and Items }} & \multirow{2}{*}{ 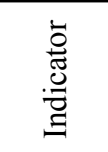 } & \multirow{2}{*}{ 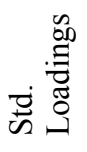 } & \multirow[b]{2}{*}{ 吾泀 } & \multicolumn{2}{|c|}{ Reliability Test } & \multirow[b]{2}{*}{$\mathrm{AVE}^{* *}$} & \multicolumn{2}{|c|}{ Validity Test } \\
\hline & & & & & $\begin{array}{c}\text { Chrobach } \\
\text { Alpha }\end{array}$ & $\begin{array}{l}\text { Composite } \\
\text { Reliability* }\end{array}$ & & GFI & RMSEA \\
\hline \multirow{8}{*}{$\begin{array}{l}0 \\
0 \\
0 \\
4 \\
\pm \\
.0 \\
0\end{array}$} & \multirow{4}{*}{$\begin{array}{l}\text { Joint } \\
\text { Decision } \\
\text { Making } \\
\text { (JDM) }\end{array}$} & JDM1 & 0.87 & 4 & 0.907 & 0.9014 & 0.6968 & 0.98 & 0.047 \\
\hline & & JDM2 & 0.73 & & & & & & \\
\hline & & JDM3 & 0.84 & & & & & & \\
\hline & & JDM4 & 0.89 & & & & & & \\
\hline & \multirow{4}{*}{$\begin{array}{l}\text { Win-Win } \\
\text { Approach } \\
\text { (WWA) }\end{array}$} & WWA1 & 0.80 & 4 & 0.884 & 0.8424 & 0.5735 & 0.98 & 0.056 \\
\hline & & WWA2 & 0.67 & & & & & & \\
\hline & & WWA3 & 0.73 & & & & & & \\
\hline & & WWA4 & 0.82 & & & & & & \\
\hline
\end{tabular}

Notes: *Composite Reliability $\left.(\mathrm{CR})=(\Sigma \lambda i)^{2} /\left[(\Sigma \lambda i)^{2}+\Sigma \delta i\right)\right],(\lambda i=$ standardized factor loadings, $i=$

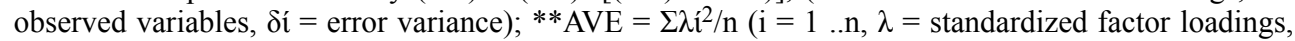
$\mathrm{i}=$ observed variables)

\subsubsection{Profiles of responding firms}

As shown in Table 2, the majority of firms responding to the survey were manufacturers $(n=109)$, with $21.8 \%$ final product manufacturers, followed by services firms $(n=93)$.

Table 2. Profile of the responding firms

\begin{tabular}{|c|c|c|c|c|}
\hline Profile & $\begin{array}{l}\text { Number of } \\
\text { Respondents }\end{array}$ & Category & Count & Percentage \\
\hline \multirow{2}{*}{$\begin{array}{l}\text { Organizational } \\
\text { Category }\end{array}$} & 202 & Manufacturing & 109 & 54 \\
\hline & & Service & 93 & 46 \\
\hline \multirow[t]{8}{*}{ Business Function } & 201 & Miner/Raw Material Extrator & 9 & 4.5 \\
\hline & & Raw Material Manufacturer & 29 & 14.4 \\
\hline & & Component Manufacturer & 27 & 13.4 \\
\hline & & Final Product Manufacturer & 44 & 21.8 \\
\hline & & Wholesaler & 19 & 9.4 \\
\hline & & Retailer & 13 & 6.4 \\
\hline & & Services & 53 & 26.2 \\
\hline & & Others & 7 & 3.5 \\
\hline \multirow{3}{*}{$\begin{array}{l}\text { Contract } \\
\text { Arrangments }\end{array}$} & 113 & Formal Contract with suppliers & 12 & 5.9 \\
\hline & & Formal Contract with customers & 3 & 1.5 \\
\hline & & No Contract Arrangment & 97 & 48 \\
\hline \multirow[t]{3}{*}{ ISO Certification } & 202 & Yes & 46 & 22.8 \\
\hline & & No & 151 & 74.8 \\
\hline & & Other quality assurance program & 6 & 2.5 \\
\hline
\end{tabular}


Only $12(5.9 \%)$ and $3(1.5 \%)$ have contracts with the suppliers and customers, respectively. With regard to the quality assurance programs, 46 respondent firms $(22.8 \%)$ were ISO-certified.

In this study, we included both manufacturing and services firms because activities within the entire supply chain involve service firms such as logistics provider and insurance company. As displayed in Table 3, the independent $t$-tests results indicated no significant differences were found on the variables between the responses from manufacturing and service companies illustrating that combining data from both industries yielded no difference.

\subsubsection{Correlation analysis: relationships between variables}

The correlation matrix presented in Table 4 shows Pearson's correlation coefficients between the independent and dependent variables. Since all of the r-values were less than 0.90, we conclude that there was no evidence of multicollinearity (Hair et al. 2006).

\subsubsection{Structural model}

Path coefficients were calculated using SEM to examine the relationships between TQM, KM and SCL. In order to test the structural model, multiple fit indices were used: (1) Chi-Square $\left(\chi^{2}\right)$ statistics to the degree of freedom $(d f) ;(2)$ the absolute fit index (GFI and RMSEA); (3) the comparative fit index (CFI) and (4) the normed-fit index (NFI) to evaluate the goodness of fit of the measurement model. Hair et al. (2006) argued that GFI, CFI and NFI values that above 0.90 are indication of a satisfactory model of fit. As shown in Figure 2, the structural model analysis had a reasonably good fit for the data collected $\left[\chi^{2}=122.54, d f=101\right.$, GFI $=0.87, \mathrm{CFI}=1.00, \mathrm{NFI}=0.98$, RMSEA $=0.046]$, albeit with slightly lower values of GFI. The ratios of chi-square to degree of freedom were 1.21 which is less than the conventionally accepted standard of 3.0 (Ju et al. 2006).

\section{Summary of findings and conclusion}

\subsection{Summary of findings}

Based on the conceptual framework proposed for TQM, KM and SCL and on the empirical validation of the model, the following findings may be useful for further investigation and applications in practice:

- The results of bivariate correlations between TQM, KM and SCL revealed that there was a relatively high correlation exists between variables examined in this study. This suggests that the predictor variables: total quality management practices and knowledge management practices are closely related with the outcome variable, the supply chain learning.

- Scales with good measurement properties commonly exhibit high factor loadings. All of the sub-scales for TQM, KM and SCL have high factor loadings ranging from 0.79 to $0.89 ; 0.81$ to 0.87 ; and 0.81 to 0.88 respectively showing that these sub-scales are appropriate for measuring the three constructs used in the study. Details of validity and reliability results are demonstrated in Table 1. 
Table 3. Independent T-Tests statistics for estimating difference in responses between manufacturing and service companies

\begin{tabular}{|c|c|c|c|c|c|c|}
\hline Variables & Category & $\mathrm{N}$ & Mean & $\begin{array}{c}\text { Std. } \\
\text { Deviation }\end{array}$ & $\begin{array}{l}\text { Std. Error } \\
\text { Mean }\end{array}$ & Significance \\
\hline \multicolumn{7}{|l|}{ TQM Practices } \\
\hline \multirow[t]{2}{*}{ Leadership } & Manufacturing & 109 & 3.875 & 0.707 & 0.067 & \multirow[t]{2}{*}{ n.s. } \\
\hline & Service & 93 & 3.974 & 0.695 & 0.663 & \\
\hline \multirow[t]{2}{*}{ Strategic Planning } & Manufacturing & 109 & 3.936 & 0.624 & 0.060 & \multirow[t]{2}{*}{ n.s. } \\
\hline & Service & 93 & 3.963 & 0.633 & 0.066 & \\
\hline \multirow[t]{2}{*}{ Customer Focus } & Manufacturing & 109 & 3.918 & 0.781 & 0.075 & \multirow[t]{2}{*}{ n.s. } \\
\hline & Service & 93 & 3.772 & 0.725 & 0.075 & \\
\hline \multirow[t]{2}{*}{ Process Management } & Manufacturing & 109 & 3.797 & 0.659 & 0.063 & \multirow[t]{2}{*}{ n.s. } \\
\hline & Service & 93 & 3.912 & 0.617 & 0.064 & \\
\hline \multirow[t]{2}{*}{ Information Analysis } & Manufacturing & 109 & 3.845 & 0.809 & 0.077 & \multirow[t]{2}{*}{ n.s. } \\
\hline & Service & 93 & 3.887 & 0.740 & 0.077 & \\
\hline Human Resource & Manufacturing & 109 & 3.822 & 0.727 & 0.070 & \multirow[t]{2}{*}{ n.s. } \\
\hline Focus & Service & 93 & 3.948 & 0.674 & 0.069 & \\
\hline \multicolumn{7}{|l|}{ KM Practices } \\
\hline \multirow[t]{2}{*}{ KM Process } & Manufacturing & 109 & 3.722 & 0.619 & 0.060 & \multirow[t]{2}{*}{ n.s. } \\
\hline & Service & 93 & 3.742 & 0.662 & 0.069 & \\
\hline \multirow[t]{2}{*}{ Leadership in $\mathrm{KM}$} & Manufacturing & 109 & 3.872 & 0.675 & 0.065 & \multirow[t]{2}{*}{ n.s. } \\
\hline & Service & 93 & 3.871 & 0.760 & 0.079 & \\
\hline \multirow[t]{2}{*}{ KM Culture } & Manufacturing & 109 & 3.882 & 0.706 & 0.068 & \multirow[t]{2}{*}{ n.s. } \\
\hline & Service & 93 & 3.879 & 0.704 & 0.073 & \\
\hline \multirow[t]{2}{*}{ KM Technology } & Manufacturing & 109 & 3.912 & 0.775 & 0.074 & \multirow[t]{2}{*}{ n.s. } \\
\hline & Service & 93 & 3.778 & 0.706 & 0.073 & \\
\hline \multirow[t]{2}{*}{ KM Measurement } & Manufacturing & 109 & 3.844 & 0.764 & 0.072 & \multirow[t]{2}{*}{ n.s. } \\
\hline & Service & 93 & 3.847 & 0.732 & 0.076 & \\
\hline \multicolumn{7}{|l|}{ Supply Chain Learning } \\
\hline \multirow[t]{2}{*}{ Absorptive Capacity } & Manufacturing & 109 & 3.832 & 0.687 & 0.066 & \multirow[t]{2}{*}{ n.s. } \\
\hline & Service & 93 & 3.769 & 0.672 & 0.065 & \\
\hline \multirow{2}{*}{$\begin{array}{l}\text { Pre-learning } \\
\text { Conditions }\end{array}$} & Manufacturing & 109 & 3.835 & 0.677 & 0.065 & \multirow[t]{2}{*}{ n.s. } \\
\hline & Service & 93 & 3.855 & 0.622 & 0.065 & \\
\hline Learning Enablers & Manufacturing & 109 & 3.774 & 0.693 & 0.066 & n.s. \\
\hline & Service & 93 & 3.743 & 0.784 & 0.081 & \\
\hline Learning Support/ & Manufacturing & 109 & 3.851 & 0.726 & 0.070 & n.s. \\
\hline System & Service & 93 & 3.757 & 0.761 & 0.079 & \\
\hline Joint Efforts & Manufacturing & 109 & 3.875 & 0.706 & 0.068 & n.s. \\
\hline & Service & 93 & 3.841 & 0.699 & 0.073 & \\
\hline
\end{tabular}

Note: n.s. non significant 


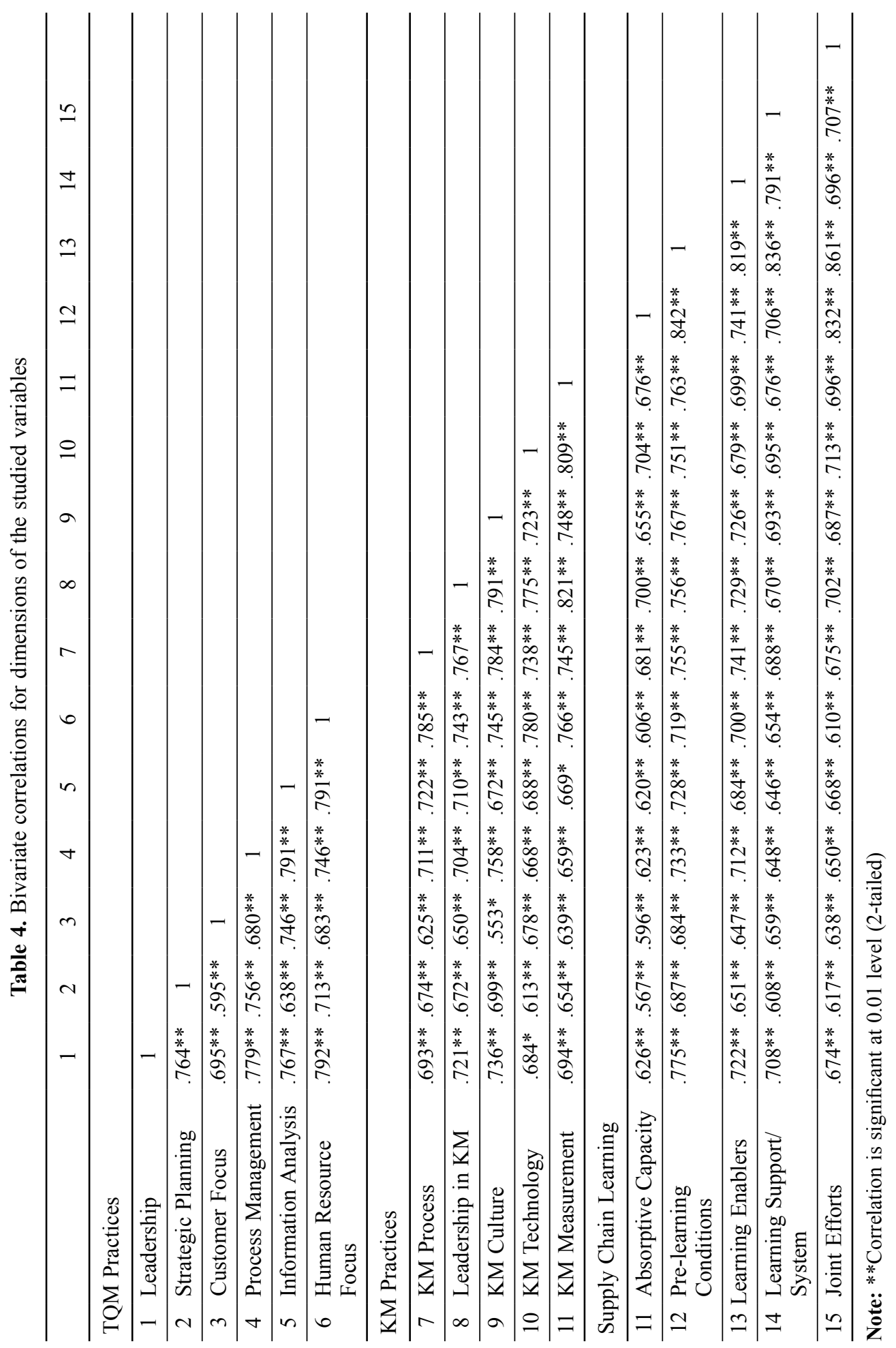




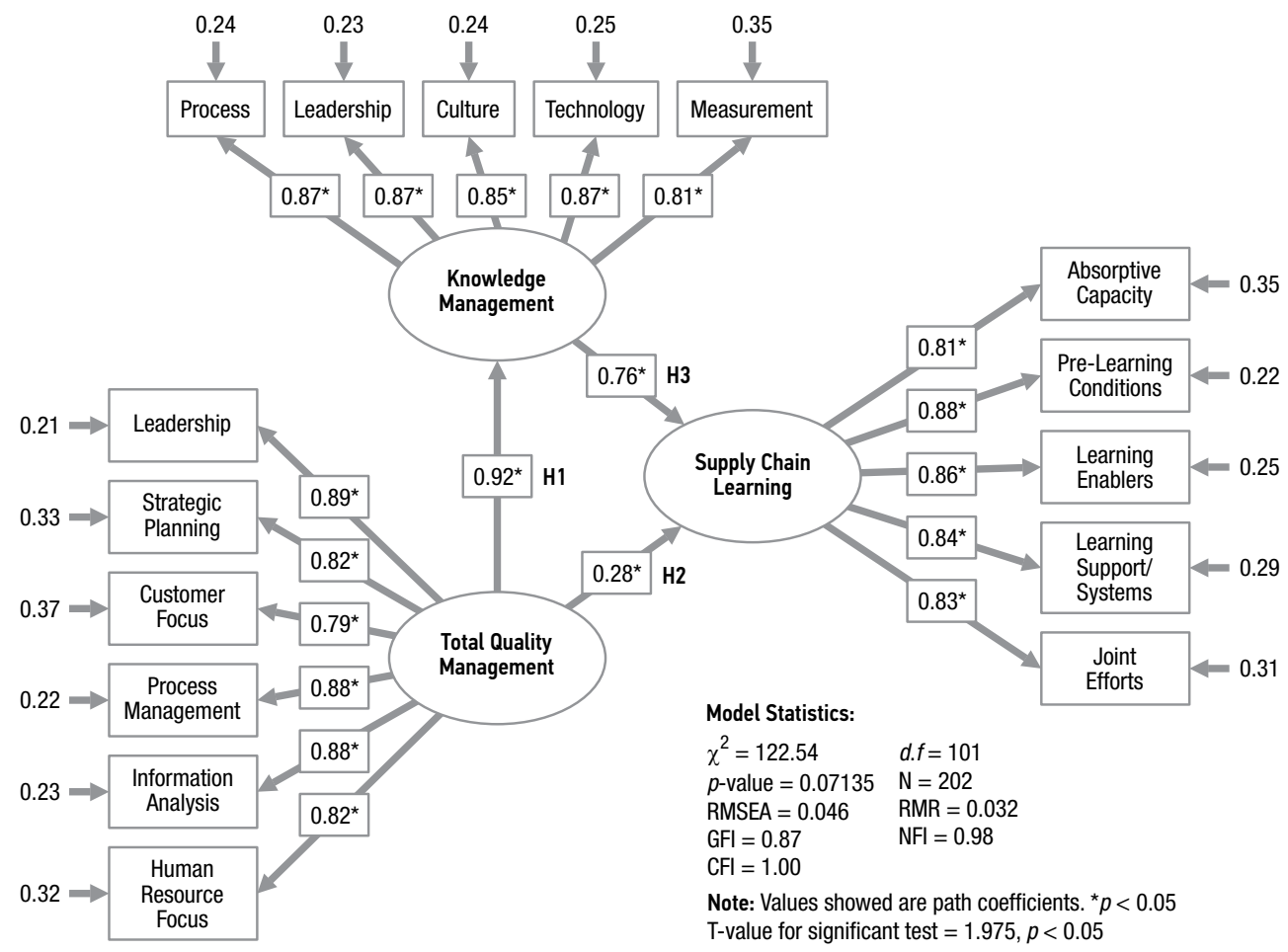

Fig. 2. Path analysis results

- All of the hypothesis 1, 2, and 3 were found to be significant. This shows that TQM practices have significant positive relationships to knowledge management $\left(\mathrm{H}_{1}\right)$, with a path coefficient of $0.92 ; p<0.01$, and to supply chain learning $\left(\mathrm{H}_{2}\right)$, with a path coefficient of $0.28 ; p<0.05$. This means that high levels of TQM practice lead to greater levels of KM practices and greater learning among supply chain partners. The results also demonstrated the positive significant relationship between $\mathrm{KM}$ practice, and SCL $\left(\mathrm{H}_{3}\right)$, with a path coefficient of $0.76 ; p<0.01$. The presence of each KM component such as KM process, leadership, culture, technology and measurement has a direct impact on a firm's ability to support learning within the supply chain. Since the factor loading for the pre-learning conditions on SCL is highest, that is 0.88 , it would be fair to say that KM and TQM practices contribute to the greatest extent to pre-learning conditions when compared to other subscales measuring the absorptive capacity and learning behavior of the responding firms. The study showed that learning can be realized across firms and can be extended to the whole supply chain through collaboration. Both TQM and KM have positive impact on SCL but KM practices seemed to have stronger impact on SCL as compared to TQM. 


\subsection{Conclusions}

Quality management applied in supply chain has evolved over times. The traditional company- centered quality effort has expanded to the entire supply chain systems and such paradigm shift focuses more on supplier-customer relationships and co-making of quality products (Levy 1998; Kuei, Madu 2001; Lin et al. 2005). Spekman et al. (2002) suggested that greater level of inter-firm collaborations can be achieved through supply chain learning, particularly when partners learning from their past mistakes. The purpose of this paper was to provide a theoretical framework that ties interrelated bodies of knowledge in examining the supply chain learning. Firms are constantly seeking for new ways to gain a sustainable competitive edge. We demonstrated that, through the empirical evidence, how these two important strategies: TQM and KM can be integrated to increase knowledge creation and subsequently to increase performance and profitability. The five dimensions of TQM used in this study were: leadership, strategic planning, customer focus, process management, information analysis and human resource focus. We relied on the work tools developed by the American Productivity \& Quality Center (APQC) and Arthur Anderson in examining five areas of knowledge management practices, namely KM process, KM leadership, KM culture, technology and KM measurement.

In addition, we adopted a similar approach used by Spekman et al. (2002) in measuring supply chain learning. Our study has contributed to a better understanding of supply chain learning and the type of practices needed to facilitate greater learning activities between partnering firms. We found that TQM practices promote higher level of KM practices. This is because the implementation of quality planning, control and assurance requires regular reviews and continuous inputs to enable and sustain excellence in performance. Proper documentations and supporting systems foster sharing of information within the firm and between supply chain partnering firms. These can serve to be the basis not only for measuring product yield and productivity, but also for improving overall quality performance such as increased efficiency in tasks coordination.

In addition, the results of this study showed that firms that are committed to quality management most likely to have higher level of learning because: (1) they are found to be more inclined to devote resources in technology and information systems that support the learning activities; and (2) supply chain partners are more prone to share since creation of new knowledge capabilities are believed to enhance their competitiveness. In fact, partner participation in identifying and solving problems is useful for improving quality and productivity. More importantly, significant cost reduction is expected. These benefits are most likely to be spanned over the whole supply chain due to better forecasting, lower rework and product returns, and increased customer satisfaction. Ghosh and Skibniewski (2010) pointed out that the enterprise resource planning (ERP) systems commonly require changes in business processes to best practices determined by the ERP vendor's supported system which may not match with the ERP adopter's business processes. Therefore, firms must be willing to continue to learn and adapt in order to succeed within the context of environmental complexities. 
Consistent with previous findings e.g. Saraph, Benson and Schroeder (1989); Das, Kumar, K. and Kumar, U. (2011), leadership is found to be an important element for any quality improvement. An effective implementation of TQM requires the managers to have sound communication and interpersonal skills so that the firm's vision and objectives are properly communicated to everyone in the organization. The ability to encourage discussion, feedback and employee involvement ensures quality efforts can be achieved.

Strategic planning helps firms to effectively allocate resources for quality performance. This includes formulating programs or operational plans and policies gearing towards the firm's vision, mission and objectives. Efficient process management and information analysis enhance creative problem-solving and decision-making. Such processes can be expanded to team learning behavior and thereby benefit all members in the chain. Indeed, participation from management team and employees, as well as supply chain partners is key for any adjustment, update and corrections in the firm's strategy. This is because the goals of the firms are needed to be continuously re-evaluated and revised in today fast changing world.

According to Armistead (1999), knowledge management can be valuable when it is applied in an operational context since information collected will be utilized strategically for planning in future include new designs for products and services. Similar to findings in study by Sambasivan et al. (2009), we found that each component of KM practices is important from fostering closer relationship between supply chain partners (both upstream and downstream) to the realization of synergies arising from collaboration. Coordination of activities and tasks between partnering firms requires communication and mutual adjustment including learning from each others. Our findings have provided support for the argument that KM process, leadership, culture, technology and measurement must all be in place to promote learning. Implementation of TQM and $\mathrm{KM}$ requires long-term commitment to realize their benefits because the nature of these practices is complex and is known as a company-wide initiative. Nevertheless, through learning, knowledge creation and processes innovation, partnering firms within the supply chain are able to adapt better in a highly dynamic and uncertain environment by focusing on quality movements.

\subsection{Future research directions}

An attempt has been made in this research to study TQM and KM in learning within a supply chain network through empirical data collection and analysis. The following are some potential directions for future research.

First, future studies can be conducted to explore the impact of SCL on performance measures. Research questions should focus on whether higher levels of SCL will improve supply chain performance through increased efficiency and cost reduction. Studies are also needed to determine the extent to which SCL enhances a firm's capability to innovate or engage in new product development. The extent to which levels of SCL affect partner satisfaction with and commitment to alliance structures should also be investigated. 
Second, this study used a fairly wide range of both manufacturing and services firms in Malaysia. With larger sample sizes in future study, it will be interesting to compare whether the same model can be sustained when the category of industry is confined. Further, we suggest future researchers explore the use of qualitative, non-survey techniques such as interviews and field observations.

\section{Acknowledgement}

The authors would like to thank the Ministry of Higher Education Malaysia for financially supporting this research under Project No: 600-RMI/SPP/FRGS 5/3/Fsp (48/2010).

\section{References}

Akande, W. A.; Adetoun, B. E.; Tserere, M. M.; Adewuyi, M. F.; Akande, E. T. 2010. Should we put locals in charge? Managing relationships within prospective us - South African joint ventures, Journal of Business Economics and Management 11(4): 550-575.

http://dx.doi.org/10.3846/jbem.2010.27

Al-Hawari, M.; Ward, T. 2006. The effect of automated service quality on Australian banks' financial performance and the mediating role of customer satisfaction, Marketing Intelligence and Planning 24(2): 127-147. http://dx.doi.org/10.1108/02634500610653991

Anderson, J. C.; Gerbing, D. W. 1988. Structural equation modeling in practice: a review and recommended two-step approach, Psychological Bulletin 103(3): 411-423.

http://dx.doi.org/10.1037/0033-2909.103.3.411

Armistead, C. 1999. Knowledge management and process performance, Journal of Knowledge Management 3(2): 143-154. http://dx.doi.org/10.1108/13673279910275602

Bagozzi, R. P.; Yi, Y. 1988. On the evaluation of structural equation models, Journal of the Academy of Marketing Science 16(1): 74-94. http://dx.doi.org/10.1007/BF02723327

Bessant, J.; Kaplinsky, R.; Lamming, R. 2003. Putting supply chain learning into practice, International Journal of Operations and Management 23(2): 167-184.

http://dx.doi.org/10.1108/01443570310458438

Browne, M. W.; Cudeck, R. 1993. Alternative Ways of Assessing Model Fit. Newbury Park, CA: Sage Publications.

Carmignani, G. 2009. Supply chain and quality management: the definition of a standard to implement a process management system in a supply chain, Business Process Management Journal 15(3): 395-407. http://dx.doi.org/10.1108/14637150910960639

Chawla, D.; Joshi, H. 2010. Knowledge management practices in Indian industries - a comparative study, Journal of Knowledge Management 14(5): 708-725.

http://dx.doi.org/10.1108/13673271011074854

Chen, H.; Lee, P.; Lay, T. 2009. Drivers of dynamic learning and dynamic competitive capabilities in international strategic alliances, Journal of Business Research 62(12): 1289-1295.

http://dx.doi.org/10.1016/j.jbusres.2008.12.003

Choi, T. Y.; Eboch, K. 1998. The TQM paradox: relations among TQM practices, plant performance, and customer satisfaction, Journal of Operations Management 17: 59-75.

http://dx.doi.org/10.1016/S0272-6963(98)00031-X

Chong, C. W.; Chong, S. C. 2009. Knowledge management process effectiveness: measurement of preliminary knowledge management implementation, Knowledge Management Research and Practice 7: 142-151. http://dx.doi.org/10.1057/kmrp.2009.5 
Claycomb, C.; Dröge, C.; Germain, R. 2001. Applied process knowledge and market performance: the moderating effect of environmental uncertainty, Journal of Knowledge Management 5(3): 264-278. http://dx.doi.org/10.1108/13673270110401239

Cohen, W.; Levinthal, D. 1990. Absorptive capacity: a new perspective on learning and innovation, Administrative Science Quarterly 35(1): 128-152. http://dx.doi.org/10.2307/2393553

Cox, A. 1999. Power, value and supply chain management, Supply Chain Management: an International Journal 4(4): 167-175. http://dx.doi.org/10.1108/13598549910284480

Claver-Cortes, E.; Pereira-Moliner, J.; Tari, J. J.; Molina-Azorin, J. F. 2008. TQM, managerial factors and performance in the Spanish hotel industry, Industrial Management and Data Systems 108(2): 228-244. http://dx.doi.org/10.1108/02635570810847590

Cyert, R.; March, J. 1963. Behavioral Theory of the Firm. Oxford: Blackwell.

Das, A.; Kumar, K.; Kumar, U. 2011. The role of leadership competencies for implementing TQM: an empirical study in Thai manufacturing industry, International Journal of Quality and Reliability Management 28(2): 195-219. http://dx.doi.org/10.1108/02656711111101755

Dick, G. P. M. 2000. ISO 9000 certification benefit, reality or myth?, The TQM Magazine 12(6): 365-371. http://dx.doi.org/10.1108/09544780010351517

Drucker, B. 1993. Post Capitalist Society. New York. NY: Harper Business.

Fahey, L.; Srivastava, R.; Sharon, J. S.; Smith, D. E. 2001. Linking e-business and operating processes: the role of knowledge management, IBM System Journal 40(4): 889-907.

http://dx.doi.org/10.1147/sj.404.0889

Fisher, M. L.; Raman, A.; McClelland, A. 2000. Rocket-science retailing is almost here: are you ready?, Harvard Business Review 78(4): 115-124.

Fornell, C.; Larcker, D. F. 1981. Evaluating structural equation models with unobservable variables and measurement error, Journal of Marketing Research 18(1): 39-50.

http://dx.doi.org/10.2307/3151312

Gorla, N.; Somers, T. M.; Wong, B. 2010. Organizational impact of system quality, information quality, and service quality, Journal of Strategic Information Systems 19: 207-228.

http://dx.doi.org/10.1016/j.jsis.2010.05.001

Ghosh, S.; Skibniewski, M. J. 2010. Enterprise resource planning systems implementation as a complex project: a conceptual framework, Journal of Business Economics and Management 11(4): 533-549. http://dx.doi.org/10.3846/jbem.2010.26

Grant, R. M.; Baden-Fuller, C. 2004. A knowledge accessing theory of strategic alliances, Journal of Management Studies 41(1): 61-84. http://dx.doi.org/10.1111/j.1467-6486.2004.00421.x

Hair, J. F.; Black, B.; Babin, B.; Anderson, R.; Tatham, R. L. 2006. Multivariate Data Analysis. $6^{\text {th }}$ ed. Pearson International.

Hall, R. 1999. Rearranging risks and rewards in supply chain management, Journal of General Management 24(3): 22-32.

Ho, L.-A. 2008. What affects organizational performance? The linking of learning and knowledge management, Industrial Management and Data Systems 108(9): 1234-1254.

http://dx.doi.org/10.1108/02635570810914919

Hsieh, C. T.; Lin, B.; Manduca, B. 2007. Information technology and six sigma implementation, Journal of Computer Information Systems XLVII(4): 1-10.

Jabar, J.; Sooday, C.; Santa, R. 2011. Organizational learning as an antecedent of technology transfer and new product development: a study of manufacturing firms in Malaysia, Journal of Manufacturing Technology Management 22(1): 25-45. http://dx.doi.org/10.1108/17410381111099798 Jasimuddin, S. M. 2008. A holistic view of knowledge management strategy, Journal of Knowledge Management 12(2): 57-66. http://dx.doi.org/10.1108/13673270810859514 
Johannessen, J.; Olsen, B. 2003. Knowledge management and sustainable competitive advantage: the impact of dynamic contextual training, International Journal of Information Management 23(4): 277-289. http://dx.doi.org/10.1016/S0268-4012(03)00050-1

Ju, T. L.; Lin, B.; Lin, C.; Kuo, H.-J. 2006. TQM critical factors and KM value chain activities, Total Quality Management and Business Excellence 17(3): 373-393.

http://dx.doi.org/10.1080/14783360500451614

Kline, R. B. 1998. Principles and Practice of Structural Equation Modeling. New York: The Guilford Press.

Kordupleski, R. E.; Rust, R. T.; Zahorik, A. J. 1993. Why improving quality doesn't improve quality?, California Management Review 35(3): 13-30.

Kuei, C.; Madu, C. N. 2001. Identifying critical success factors for supply chain quality management, Asia Pacific Management Review 6(4): 409-423.

Kuei, C.; Madu, C. N.; Lin, C. 2001. The relationship between supply chain quality management practices and organizational performance, International Journal of Quality Management and Reliability Management 18(8): 864-872. http://dx.doi.org/10.1108/EUM0000000006031

Lane, P. J.; Salk, J. E.; Lyles, M. A. 2001. Absorptive capacity, learning and performance in international joint ventures, Strategic Management Journal 22: 1139-1161.

http://dx.doi.org/10.1002/smj.206

Lin, C.; Chow, W. S.; Madu, C. N.; Kuei, C.-H.; Yu, P. P. 2005. A structural equation model of supply chain quality management and organizational performance, International Journal of Production Economics 96: 355-365. http://dx.doi.org/10.1016/j.ijpe.2004.05.009

Lin, H. F. 2011. Antecedents of the stage-based knowledge management evolution, Journal of Knowledge Management 15(1): 136-155. http://dx.doi.org/10.1108/13673271111108747

Lee, Y.; Kincade, D. H. 2003. US apparel manufacturers' company characteristic differences based on SCM activities, Journal of Fashion Marketing and Management 7(10): 31-48.

http://dx.doi.org/10.1108/13612020310464359

Lee, S. M.; Rho, B.-H.; Lee, S.-G. 2003. Impact of Malcolm Baldrige National Quality Award criteria on organizational quality performance, International Journal of Production Research 41(9): 2003-2020. http://dx.doi.org/10.1080/0020754031000077329

Levy, P. 1998. Total quality management in the supply chain, in Madu, C. N. (Ed.). Handbook of TQM. Kluwer Academic, London, 275-303.

Lockamy, A. III; McCormack, K. 2004. Linking SCOR planning practices to supply chain performance: an exploratory study, International Journal of Operations and Production Management 24(12): 1192-1218. http://dx.doi.org/10.1108/01443570410569010

Loke, S. P.; Downe, A. G.; Sambasivan, M.; Khalid, K.; Ooi, K. B. 2011. Integrating total quality management and knowledge management to supply chain learning: a structural approach, International Proceedings of Economics Development and Research 11: 42-47.

Loke, S. P.; Ooi, K. B.; Tan, B. I.; Safa, M. S. 2010. The role of TQM and KM in supply chain learning: a conceptual model, International of Journal of Innovation and Learning 8(3): 332-344. http://dx.doi.org/10.1504/IJIL.2010.035034

Loke, S. P.; Sambasivan, M.; Downe, A. G. 2009. Strategic alliance outcomes in supply chain environments: Malaysian case studies, European Journal of Social Sciences 9(3): 371-386.

Lyons, K.; Acsente, D.; van Waesberghe, M. 2008. Integrating knowledge management and quality management to sustain knowledge enabled excellence in performance, VINE The Journal of Information and Knowledge Management Systems 38(2): 241-253.

Manning, L.; Baines, R. N.; Chadd, S. A. 2006. Quality assurance models in the food supply chain, British Food Journal 108(2): 91-104. http://dx.doi.org/10.1108/00070700610644915 
Maqsood, T.; Walker, D.; Finegan, A. 2007. Extending the 'knowledge advantage': creating learning chains, The Learning Organization 14: 123-141. http://dx.doi.org/10.1108/09696470710726998

McAdam, R.; Henderson, J. 2004. Influencing the future of TQM: internal and external driving factors, International Journal of Quality and Reliability Management 21(1): 51-71.

http://dx.doi.org/10.1108/02656710410511696

Mellat-Parast, M.; Digman, L. A. 2008. Learning: the interface of quality management and strategic alliances, International Journal of Production Economics 114: 820-829.

http://dx.doi.org/10.1016/j.ijpe.2008.04.003

Mills, J.; Schmitz, J.; Frizelle, G. 2004. A strategic review of supply networks, International Journal of Operations and Production Management 24(10): 1012-1036.

http://dx.doi.org/10.1108/01443570410558058

Molina, L. M.; Montes, J. L.; Ruiz-Moreno, A. 2007. Relationship between quality management practices and knowledge transfer, Journal of Operations Management 26: 682-701.

http://dx.doi.org/10.1016/j.jom.2006.04.007

Nielsen, B. B. 2005. The role of knowledge embeddedness in the creation of synergies in strategic alliances, Journal of Business Research 58(9): 1194-1204.

http://dx.doi.org/10.1016/j.jbusres.2004.05.001

Phusavat, K.; Kanchan, R. 2008. Future competitiveness: viewpoints from manufacturers and service providers, Industrial Management and Data Systems 108(2): 191-207.

http://dx.doi.org/10.1108/02635570810847572

Prajogo, D. I.; Hong, S. W. 2008. The effect of TQM on performance in R\&D environments: a perspective from South Korean firms, Technovation 38: 855-863.

http://dx.doi.org/10.1016/j.technovation.2008.06.001

Prajogo, D. I.; Sohal, A. S. 2003. The relationship between TQM practices, quality performance, and innovation performance: an empirical examination, International Journal of Quality and Reliability Management 20(8): 901-918. http://dx.doi.org/10.1108/02656710310493625

Romano, P.; Vinelli, A. 2001. Quality management in a supply chain perspective: strategic and operative choices in a textile-apparel network, International Journal of Operations and Production Management 21(4): 446-460. http://dx.doi.org/10.1108/01443570110381363

Sambasivan, M.; Loke, S. P.; Abidin-Mohamed, Z. 2009. Impact of knowledge management in supply chain management: a study in manufacturing companies, Knowledge and Process Management 16(3): 111-123. http://dx.doi.org/10.1002/kpm.328

Samson, D.; Terziovski, M. 1999. The relationship between total quality management practices and operational performance, Journal of Operations Management 17: 393-409.

http://dx.doi.org/10.1016/S0272-6963(98)00046-1

Saraph, J. V.; Benson, P. G.; Schroeder, R. G. 1989. An instrument for measuring the critical factors of quality management, Decision Sciences 20(4): 810-829.

http://dx.doi.org/10.1111/j.1540-5915.1989.tb01421.x

Schein, E. 2002. The anxiety of learning, Harvard Business Review 80(1): 100-106.

Schröder, M. J. A.; McEachern, M. G. 2002. ISO 9001 as an audit frame for integrated quality management in meat supply chains: the example of Scottish beef, Managerial Auditing Journal 17(1-2): 79-85. http://dx.doi.org/10.1108/02686900210412289

Slack, N.; Chambers, S.; Johnston, R. 2004. Operation Management. $4^{\text {th }}$ ed. London: Prentice-Hall.

Sohal, A.; Morrison, M. 1995. TQM and the learning organization, Managing Service Quality 5(6): 32-34. http://dx.doi.org/10.1108/09604529510104365

Shin, M.; Holden, T.; Schmidt, R. A. 2001. From knowledge theory to management practice: towards an integrated approach, Information Processing and Management 37(2): 335-355.

http://dx.doi.org/10.1016/S0306-4573(00)00031-5 
Spekman, R. E.; Spear, J.; Kamauff, J. 2002. Supply chain competency: learning as a key component, International Journal of Supply Chain Management 7(1): 41-55.

http://dx.doi.org/10.1108/13598540210414373

Sitkin, S. M.; Sutcliffe, K. M.; Schroeder, R. G. 1994. Distinguishing control from learning in total quality management: a contingency perspective, Academy of Management Review 38(1): $7-23$.

Sureshchandar, G. S.; Rajendran, C.; Anantharaman, R. N. 2002. The relationship between management's perception of total quality service and customer perceptions of service quality, Total Quality Management 13(1): 69-88. http://dx.doi.org/10.1080/09544120120098573

Tan, K. C.; Lyman, S. B.; Wisner, J. D. 2002. Supply chain management: a strategic perspective, International Journal of Operations and Production Management 22(6): 614-631. http://dx.doi.org/10.1108/01443570210427659

Tarí, J. J. 2005. Components of successful total quality management, The TQM Magazine 17(2): 182-194. http://dx.doi.org/10.1108/09544780510583245

Talib, F.; Rahman, Z.; Qureshi, M. N. 2011. A study of total quality management and supply chain management practices, International Journal of Productivity and Performance Management 60(3): 268-288. http://dx.doi.org/10.1108/17410401111111998

Teh, P.-L.; Ooi, K.-B.; Yong, C.-C. 2008. Does TQM impact on role stressors? A conceptual model, Industrial Management and Data Systems 108(8): 1029-1044.

http://dx.doi.org/10.1108/02635570810904596

Vanichachinchai, A.; Igel, B. 2009. Total quality management and supply chain management: similarities and difference, The TQM Magazine 21(3): 249-260.

http://dx.doi.org/10.1108/17542730910953022

Zack, M.; McKeen, J.; Singh, S. 2009. Knowledge management and organizational performance: an exploratory analysis, Journal of Knowledge Management 13(6): 392-409.

http://dx.doi.org/10.1108/13673270910997088

Zetie, S. 2002. The quality circle approach to knowledge management, Managerial Auditing Journal 17(6): 317-321. http://dx.doi.org/10.1108/02686900210434096

Siew-Phaik LOKE is a Senior Lecturer in the Faculty of Business Management, Universiti Teknologi MARA (UiTM) Perak, Malaysia. She received her Ph.D. and Masters degree in management from the Graduate School of Management, Universiti Putra Malaysia. Her research interests include strategic alliances, supply chain management, knowledge management, services quality and service industry strategy.

Alan G. DOWNE is Associate Professor of Entrepreneurship \& Small Business Management at Curtin University Sarawak. He holds a Ph.D. from Multimedia University (Malaysia) and a Master's degree from the University of Calgary (Canada). His research interests focus on service industry strategy and operations, organisational learning in small business ventures and user acceptance of technology.

Murali SAMBASIVAN is the Head of Thesis-based Programs at Graduate school of Management at Universiti Putra Malaysia. His areas of interest are: Management Science, Operations Management, Statistics and Supply Chain Management. He has published in many international journals in various areas of management. Prof. Murali before becoming an academic worked in the industry for 10 years. He has a bachelors and a Masters degree in engineering from India and Ph.D. in Management Science from University of Alabama, USA.

Khalizani KHALID is a lecturer in the Faculty of Business Management at Universiti Teknologi MARA (UiTM) Perak, Malaysia. Her primary research interest is ethical decision making, business ethics and human resource management. Recently, she has explored issues in strategic management, organizational behaviour and ethics in biofuel. 